\title{
THE THOMAS HODGKIN PORTRAITS: A CASE OF MISTAKEN IDENTITY
}

\author{
by
}

\author{
AMALIE M. KASS* AND EDWARD H. KASS
}

\begin{abstract}
Despite his fame as a physician and social reformer, relatively few portraits of Thomas Hodgkin, MD (1798-1866), have been published. Two oil paintings, identified by the Hodgkin family as their forebear, have been a puzzle. ${ }^{1}$ The faces are remarkably dissimilar. One portrait hangs in the Gordon Museum at Guy's Hospital Medical School, its artist heretofore unknown (plate 1). It shows Dr Hodgkin seated in a large upholstered armchair. His dark hair, sharp aquiline nose, and penetrating gaze, commented upon by everyone who knew him, are its outstanding features. ${ }^{2}$ The second portrait (plate 2), presently owned by a branch of the Hodgkin family living in Ilmington in the North Cotswold hills of Warwickshire, shows the head and upper torso of a brown-haired man, with gentle eyes, a straight nose, and cleft chin. Family tradition has held that this too was the doctor, perhaps at a younger age, done by a different artist. Neither portrait is signed or dated. Now identification of both can be made with greater certainty, thanks to a third portrait recently found at Friends' House Library, London, and thanks also to the expertise of members of the staff of the National Portrait Gallery, and to the archives of the Hodgkin family and of Guy's Hospital.
\end{abstract}

\section{THE GUY'S PORTRAIT}

In January 1875, nearly nine years after Hodgkin's death and less than a year before her own, Sarah Frances Hodgkin, the doctor's widow, signed à formal deed of gift bestowing upon her nephew, Thomas Hodgkin of Newcastle upon Tyne, ${ }^{3 \text { " }}$ the oil

\footnotetext{
*Amalie M. Kass, BA, MEd, and Edward H. Kass, MD, PhD, FRCP, The Countway Library, The Channing Laboratory, Department of Medicine, Harvard Medical School, and Brigham and Women's Hospital, Boston, Massachusetts 02115, USA.

${ }^{1}$ See Michael Rose, Curator of the dead, London, Peter Owen, 1981, pp. 59-60 and accompanying illustrations.

2 "In appearance he [Hodgkin]is very peculiar and striking, being rather below the usual height, remarkably thin, straight as a ramrod, with dark piercing eyes, and such extraordinary convexity of the nose and other lineaments as never to be forgotten when once seen." William Gibson, Rambles in Europe in 1839 with sketches of prominent surgeons, physicians, medical schools, hospitals, etc., Philadelphia, Lea \& Blanchard, 1841, p. 279-280.

${ }^{3}$ Thomas Hodgkin (1831-1913), DCL, LittD., was a successful banker and a noted historian, author of Italy and her invaders and other works on early English and European history and on the Society of Friends.
} 
painting by Levine of my late beloved husband Thomas Hodgkin, M.D.". In June 1946, Robert H. Hodgkin, ${ }^{5}$ the distinguished historian and son of Thomas Hodgkin of Newcastle and grand-nephew of the doctor, offered the same portrait to Guy's Hospital. ${ }^{6}$ Robert Hodgkin was in the process of returning to his house at Ilmington from Oxford, where for the previous nine years he had been the Provost of Queen's College. The painting had been hanging "at the top of the staircase" in the Provost's house, but there was no appropriate place for it in Ilmington. The Governors of the Hospital, eager to restore Hodgkin to his rightful place among the "great triumvirate" of Guy's, ${ }^{7}$ accepted with alacrity. Wartime bombings had destroyed the Court Room, the Committee Room, and the Clerk's Office at Guy's, but the Governors promised to give the Hodgkin portrait a temporary place in the nurses' home, along with the portraits of Sir Astley Cooper, Richard Bright, and Thomas Addison. Subsequently, all four canvases were moved to the Medical School. The portrait of Cooper hangs in the entry hall of the Medical School building, and the portrait of Hodgkin, along with those of Addison and Bright, hangs in the Pathological Museum, known since 1905 as the Gordon Museum. No place could have been more appropriate; Hodgkin had established the museum during his twelve-year career at Guy's (1825-37). In answer to an enquiry about the artist, Robert Hodgkin had replied to Guy's that his "only surviving aunt says the portrait was painted by Levine", although she was "not sure how the name was spelt".

It is likely that the artist in question was Phoebus Levin, a German-born portraitist and genre painter, whose work often appeared in London between 1855 and 1878 , including exhibits at the Royal Academy and the British Institute. Levin was a member of the Society of British Artists, and one of his paintings, 'The Dancing Platform at Cremorne Gardens,' once hung in the London Museum at Kensington Palace. ${ }^{9}$ We do not know the circumstances by which Hodgkin, a modest and unassuming man, agreed to have his portrait painted, nor why Levin was chosen, but a letter from Alexander von Humboldt to Phoebus Levin, dated 27 September 1854 gives a clue. "I remember Dr. Hodgkin and his noble efforts with loving memory", wote von Humboldt. ${ }^{10}$ From his childhood, Hodgkin had greatly admired Humboldt's geographical explorations and sympathetic concern for the native Indians of South America. As a medical student in Paris, Hodgkin had met Humboldt, and he dedicated his graduation thesis at the University of Edinburgh to the famous scientist. Perhaps it was through the Humboldt connexion that Levin became Hodgkin's portraitist. The Humboldt-Levin letter also offers a clue to the

\footnotetext{
‘Hodgkin MSS., 14:130. There are microfilm copies of the Hodgkin papers at Friends' House Library, London, and the Countway Library, Harvard Medical School, Boston, USA. Citations for this paper refer to reels at the Countway Library and in our possession.

${ }^{5}$ Robert Hodgkin (1877-1951), son of Thomas Hodgkin, DCL (above), was also a historian, author of the History of the Anglo Saxons, and Provost of Queen's College, Oxford.

${ }^{6}$ Greater London Record Office, H9/GY/A 147/1-9.

'See H. C. Cameron, Mr. Guy's Hospital, 1726-1948, London, Longmans Green, 1954, p. 127.

${ }^{8}$ This was probably Alice Mary Hodgkin (1860-1955).

${ }^{9}$ See Jeremy Maas, Victorian painters, New York, G.P. Putnam, 1969, pp. 117-118; Algernon Graves, $A$ dictionary of British artists, London, Geo. Bell, 1884, p. 114.

${ }^{10}$ Durham County Record Office, D/HO/C 41/1, letter in German to "historien Maler [artist] Phoebus Levin", Berlin, from A. V. Humboldt.
} 


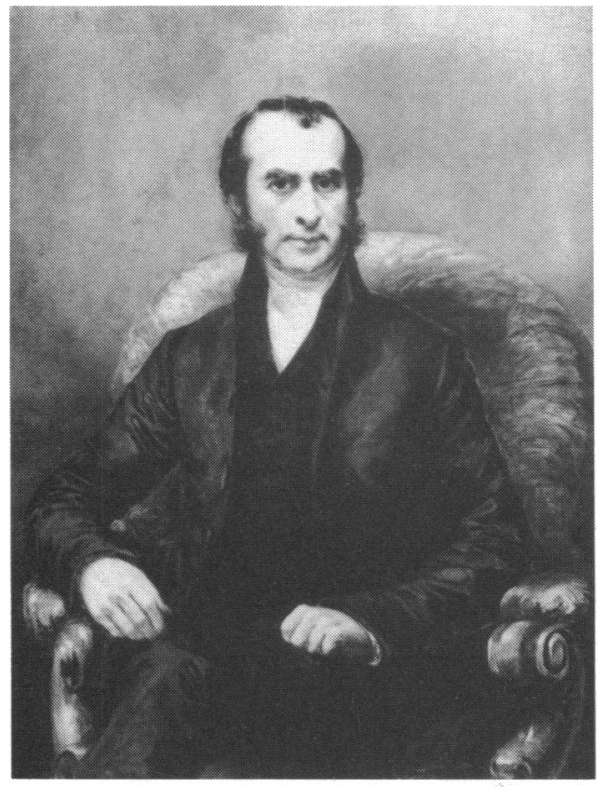

Plate 1 Thomas Hodgkin, MD, oils, $116.8 \times 96.5 \mathrm{~cm}$, presumably by Phoebus Levin. Gordon Museum, Guy's Hospital Medical School.

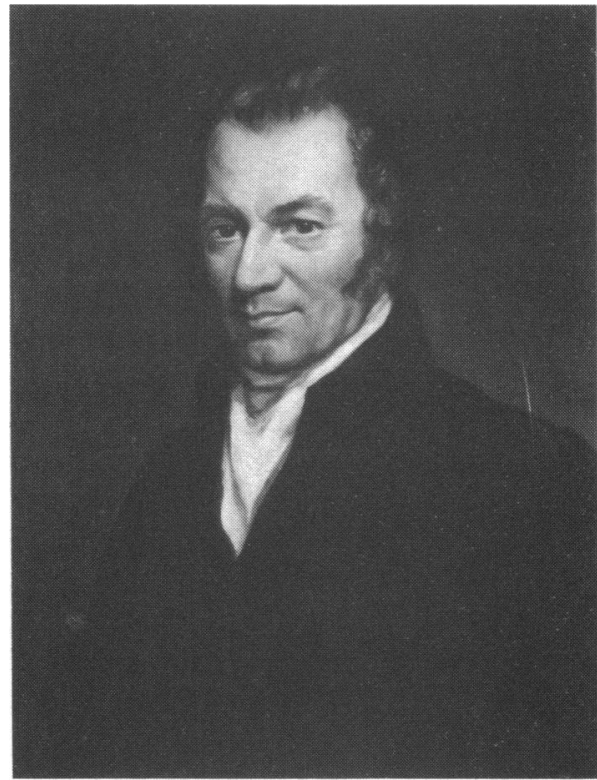

Plate 2 John Hodgkin sen., oils, $77 \times 64 \mathrm{~cm}$, copy of painting by John Opie (plate 3 ). Property of Hodgkin family, Ilmington, Warwickshire.

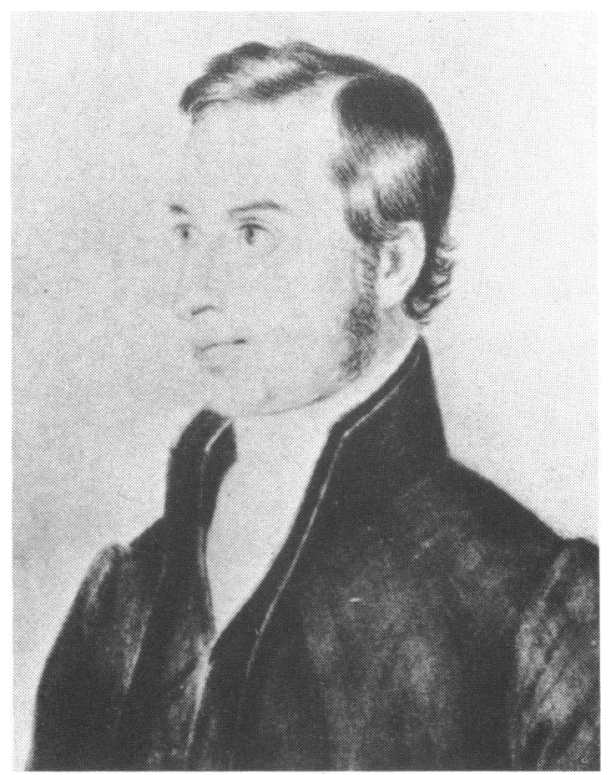

Plate 4 Thomas Hodgkin, watercolour drawing, source and date unknown. Reproduced from Barker and Robertson, op. cit., footnote 19. 


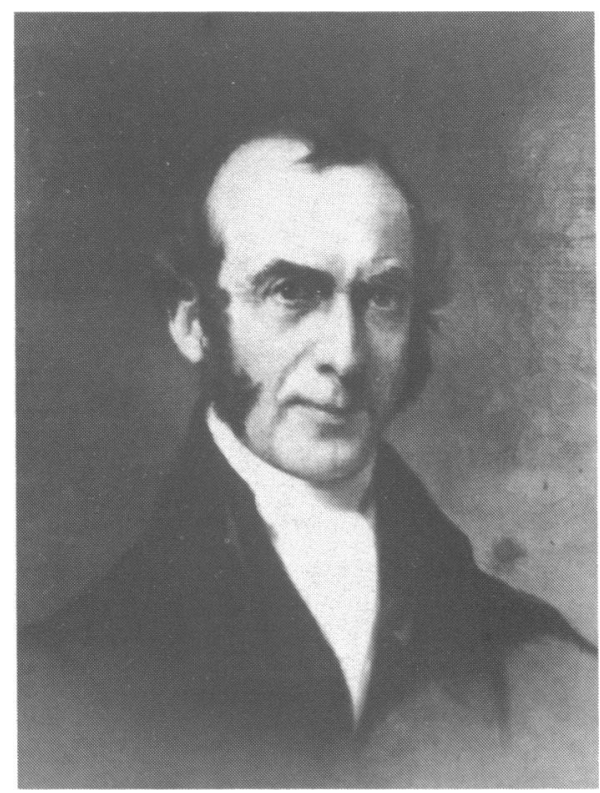

Plate 5 Thomas Hodgkin, MD, oils (from photograph), $58.2 \times 47.5 \mathrm{~cm}$, by Thomas Sully, 1858. Historical Society of Pennsylvania.

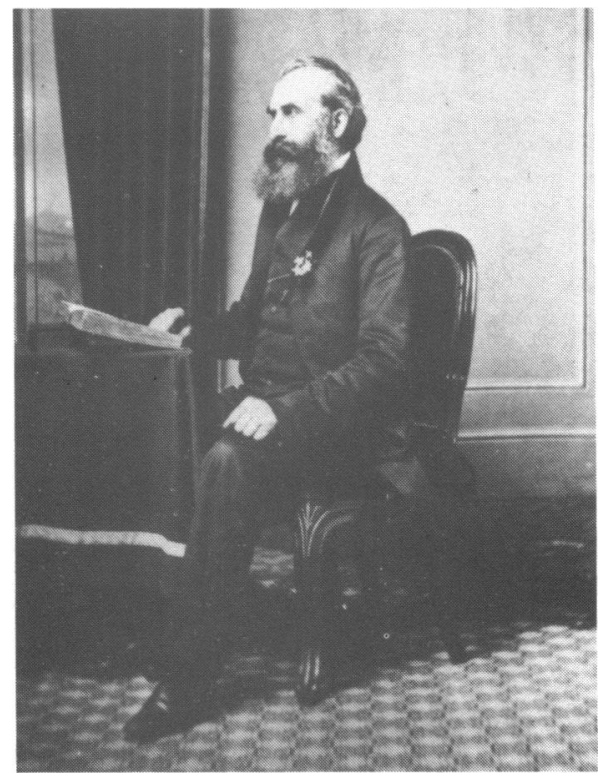

Plate 7 Thomas Hodgkin, photograph from Hodgkin family archive.

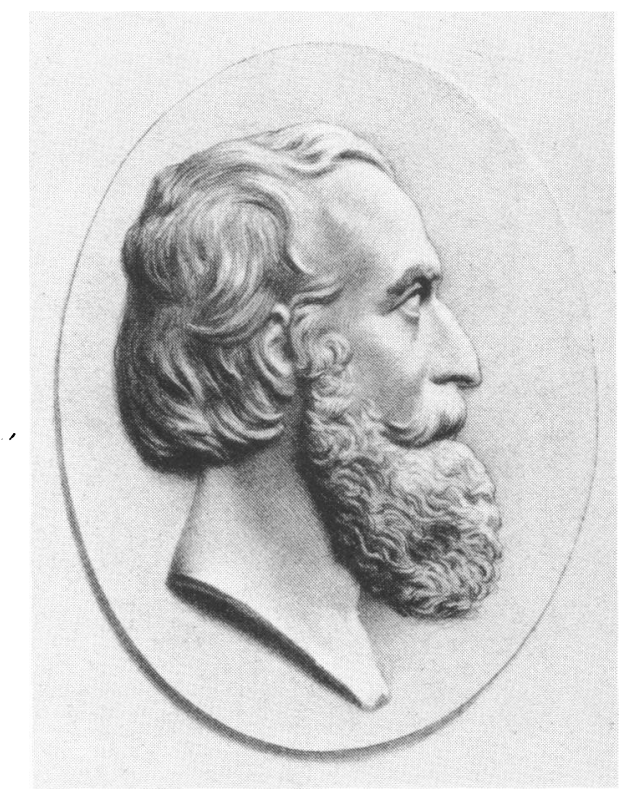

Plate 6 Thomas Hodgkin, lithograph by J. A. Vinter (from photograph), used as frontispiece to Narrative of a journey to Morocco in 1863 and 1864, by Thomas Hodgkin, MD, FRGS.

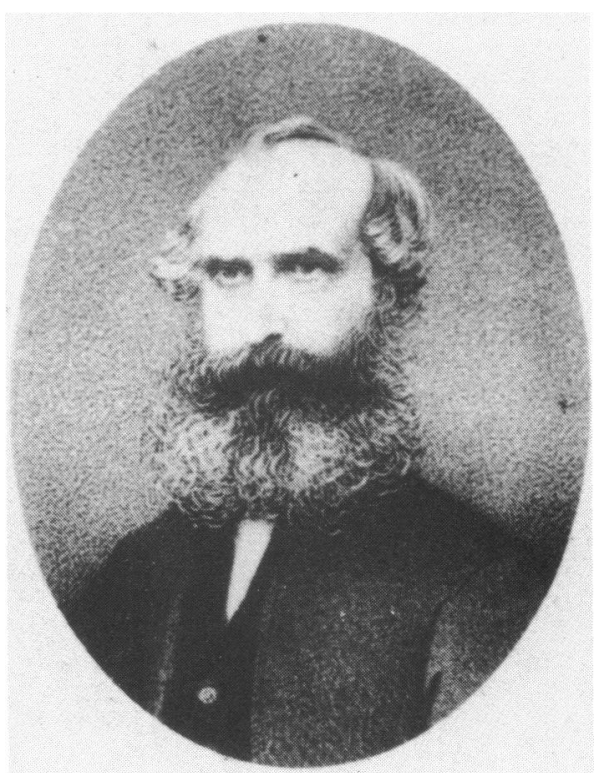

Plate 8 Thomas Hodgkin, photograph, original source unknown, presently in Wills Library, Guy's Hospital Medical School. 


\section{The Thomas Hodgkin portraits}

dating of the portrait. In 1857, Hodgkin accompanied Sir Moses Montefiore on a journey to Palestine, and when he returned he had a full beard. ${ }^{11}$ Since the Guy's portrait does not show him with a beard, and later photographs show him with this adornment, it is likely that the portrait was done some time between 1854 and 1857 . There is also mention in the Hodgkin family archives of a "Levine" portrait of the doctor's brother, John Hodgkin jun. ${ }^{12}$ Its whereabouts is presently unknown.

\section{THE ILMINGTON AND FRIENDS' HOUSE PORTRAITS}

The portrait hanging in the library of Friends' House (plate 3) was a gift made in 1974 to the Society of Friends by John Eliot Hodgkin, a descendant of the elder brother of Thomas Hodgkin of Newcastle - the elder brother was also named John Eliot Hodgkin. This branch of the family had assumed that the sitter was the doctor's father, John Hodgkin sen. ${ }^{13}$ There are two identifications marked on the back of the frame of the Friends' House portrait. One at the bottom, scratched into the wood, says "John Hodgkin of Tottenham by Opie"; the other, pencilled on the top, says "John Hodgkin by Opie". John Opie (1761-1807) was one of London's most popular portraitists. A member of the Royal Academy, he was also known for his historical paintings and illustrations and as an advocate for the formation of a British national gallery. Opie's second wife, Amelia (1769-1853), was a novelist and poet. Many years after her husband's death, Amelia Opie became a Quaker, but from her girlhood in Norfolk she had been well acquainted with members of the Society of Friends, and especially with the Gurney family. ${ }^{14}$ Since Thomas Hodgkin's mother, née Elizabeth Rickman, had been governess to the Gurney children (one of these children who became Elizabeth [Betsy] Fry was one of Amelia Opie's closest friends), it is possible that Elizabeth Rickman Hodgkin came to know Amelia Opie at that time. If not, it is clear that they were well acquainted in later years. Perhaps it was Elizabeth's friendship with Amelia that led to John Hodgkin's portrait by John Opie, although Opie himself was well known to other affluent Quakers. ${ }^{15}$ For example, a portrait of Luke Howard ${ }^{16}$ one of the Hodgkin family's closest friends, is also attributed to Opie. ${ }^{17}$

The Friends' House portrait (plate 3) is obviously of the same person as the Ilmington portrait (plate 2). Both were examined at the National Portrait Gallery and at Christie's Ltd. With no hesitation, the experts identified the Friends' House

\footnotetext{
${ }^{11}$ Guy's Hosp. Gaz., 1910, 24: 13-14. An earlier editor of the Gazette was credited with having punned as follows, "Hodgkin went out with Moses and returned with Aaron".

12 John Hodgkin jun. (1800-1875), noted barrister and Quaker minister. Father of eleven children including John Eliot Hodgkin sen., Thomas Hodgkin of Newcastle, and Alice Mary Hodgkin.

${ }^{13}$ John Hodgkin sen. (1766-1845), grammarian, calligrapher, tutor, father of Thomas Hodgkin MD, and John Hodgkin jun.

${ }^{14}$ See June Rose, Elizabeth Fry, London, Macmillan, 1980, pp. 11, 24; Jacobine Menzies-Wilson and Helen Lloyd, Amelia, the tale of a plain friend, London, Oxford University Press, 1937, pp. 18-28.

${ }^{15}$ Ada Earland, John Opie and his circle, London, Hutchinson, 1911, p. 156 and Appendix C, pp. 260-325.

${ }^{16}$ Luke Howard, FRS (1772-1864), meteorologist and chemist. His daughter Elizabeth married John Hodgkin jun. in 1829 and was the mother of John Eliot Hodgkin sen. and Thomas Hodgkin of Newcastle.

${ }^{17}$ Friends' House Library, Temp. Coll. 161, John E. Hodgkin to Executive Secretary, the Royal Meteorological Society, 9 May 1974; Executive Secretary, Royal Meteorological Society, to authors, 30 August 1984.
} 
painting as the original, and the family painting as a copy, made as much as twenty years afterwards. They also helped to substantiate the attribution to Opie on the Friends' House frame. Although it was not unusual for artists to leave their canvases unsigned, the portrait is sufficiently "in the style of Opie" to leave little room for doubt.

The face in these portraits (plates 2 and 3) would be of a healthy man in his late thirties, suggesting that Opie did the original some time in the seven years before his death, when John Hodgkin sen. would have been between thirty-five and forty-two. It conforms well to a description of John Hodgkin sen. as "strong and active, of a very bright and rather ruddy complexion, though not fair, and of a singularly happy, cheerful, equable temper."18 John Hodgkin and his family lived in Pentonville until 1814, when they moved to Tottenham, where he continued to live until his death in 1845. Hence the attribution of the frame, "John Hodgkin of Tottenham by Opie", must have been made some years after the portrait was completed. Assuming the portrait is indeed by Opie, Thomas Hodgkin, MD, was some nine years old when Opie died.

\section{OTHER PORTRAITS}

Several other portraits and some photographs of Thomas Hodgkin, MD, deserve mention, to provide a more complete catalogue and to give added evidence of his singular appearance.

1. A watercolour drawing illustrates a biographical essay on Hodgkin written shortly after his death and published in 1867 (plate 4). The features are not clearly defined, but are those of a young man. Presumably, this drawing was given to the authors of the biographical volume by members of the family. ${ }^{19}$

2. An oil painting, by Thomas Sully, belongs to the Historical Society of Pennsylvania, Philadelphia (plate 5). Hodgkin was a Vice-President and staunch advocate of the Pennsylvania Colonization Society and of its parent organization. the American Colonization Society. The American Colonization Society and its subsidiaries were responsible for establishing and supporting Liberia as a colony of American blacks on the west coast of Africa. Sully, one of the outstanding artists in Philadelphia, was commissioned by the Pennsylvania Colonization Society to do portraits of many of its leaders, including Thomas Hodgkin. The latter portrait was painted from a photograph in December 1858 and was signed by the artist. ${ }^{20}$ The supposition is that the photograph was made prior to Hodgkin's journey to Palestine and before he grew his beard. The likeness to the portrait at Guy's is evident.

3. A lithograph made by J. A. Vinter from a photograph by United Association of Photography Ltd., was used as a frontispiece to Hodgkin's Narrative of a journey to Morocco, published posthumously in 1866. Hodgkin had accompanied Sir Moses

\footnotetext{
${ }^{18}$ Autobiography of John Hodgkin jun., Hodgkin MSS, 13: 151, p. 44.

${ }^{19}$ T. H. Barker and W. T. Robertson, Photographs of eminent medical men of all countries with brief analytical notices of their works with photographic portraits from life by E. Edwards, London, John Churchill, 1867-68, vol. 2, pp. 73-76.

${ }^{20}$ Edward Biddle and Mantle Fielding, Life and works of Thomas Sully, Philadelphia, Wickersham Press, 1921, p. 174; Charles Henry Hart, A register of portraits painted by Thomas Sully, 1801-1871, Philadelphia, [privately printed], 1909, p. 81.
} 
Montefiore to Morocco during the final months of 1863 and the beginning of 1864 . The lithograph is a complete profile; the sharp nose and deep set eyes are apparent and there is a full beard. It is signed in Hodgkin's hand "Thine sincerely Thomas Hodgkin" (plate 6).

4. Two photographs, one of Hodgkin seated and the other of him standing, were made in a photography studio. These are part of a series of photographs of members of the family, including Hodgkin's wife, his brother and his brother's third wife. Hodgkin is full bearded in both photographs and has a flower in his lapel in the seated pose, an unusual bit of fancy for a generally austere, plainly dressed Quaker. The photograph of Hodgkin seated is shown in plate 7.

5. An additional photograph was supplied to us by Mr. A. Baster of the Wills Library at Guy's Hospital Medical School. The portrait was probably given to Guy's Hospital by Sir Samuel Wilks. ${ }^{11}$ It is signed "Thomas Hodgkin, M.D." (plate 8).

There is one remaining portrait to be identified. This painting, also at Friends' House, is of an older man, is attributed to Julius Sperling and is supposed to be another portrait of John Hodgkin sen. The identification on the back of the portrait spells this out, but the face is of a man so different from the Opie portrait, and so different from the description of John Hodgkin sen., that even if one were to excuse a lesser artist and the advanced age of the sitter, it seems unlikely. It is known that Sperling did a drawing of John Hodgkin sen. in 1837, but since the reference is to "100 copies" to be "taken off" after "one more sitting", it does not suggest an oil painting such as the one hanging at the Friends' Library. ${ }^{21}$ Furthermore, the subject wears a coat with velvet collar and a rather fancy shirt, not in keeping with John Hodgkin's rigorous Quaker practices. Correspondence with Dr John E. Hodgkin of Cambridge indicated that his grandfather probably bought this portrait because of the identification and that it was hung as an "ancestor" but that no one in the family believed that it was a portrait of John Hodgkin sen. We therefore cannot be confident of the identity of this painting.

Thus, by correcting a misapprehension concerning the Hodgkin portraits, we hope to have assembled a more complete record of the known portraits of Thomas Hodgkin, MD.

\section{ACKNOWLEDGEMENTS}

The authors are indebted to Professor Dorothy Hodgkin, Elizabeth Hodgkin, Edward C. Hodgkin, and Annie Humphries; to Edward Milligan and Malcolm Thomas of the Friends' House Library; to Susan Palmer, Greater London Council Archives; to Donald Bompas and Joseph Daws, of Guy's Hospital Medical School; to Dr S. Foister of the National Portrait Gallery; and to W. M. Schupbach of the Wellcome Institute Library, who kindly made available to us portrait No. 4.

${ }^{21}$ T. Hodgkin to J. Hodgkin jun, 15 May 1837, Hodgkin MSS. 7:68. 